\author{
Драгана Д. ВЕљКОВИЋ СТАНКОВИЋ \\ Филолошки факултет \\ Универзитета у Београду
}

\title{
О АНТРОПОЦЕНТРИЧНОЈ СЕМАНТИЧКОЈ ДЕРИВАЦИЈИ РЕИЛЕКСЕМА У СРПСКОМ ЈЕЗИКУ
}

\begin{abstract}
У раду полазимо од хипотезе да је семантичка деривација лексема које денотирају неживе ентитете језичка универзалија, а њени исходи, утемељени на персонификацији и антропоморфизацији, специфични у сваком језику. Циљ рада јесте испитивање фигуративних значења реилексема и когнитивнолигвистичко сагледавање човековог социјално, карактерно и емотивно условљеног етнолингвистичког профила оцртаног овим лексичкосемантичким кругом у српском језику.
\end{abstract}

Кључне речи: српски језик, реилексеме, људске особине, антропоцентрична семантичка деривација, фигуративно значење

\section{1. Уводне напомене}

1.0. Начин опојмљавања прототипичних човекових особина од стране говорника српског језика као матерњег може се посматрати кроз избор и структуру изворних домена преко којих се разумевају позитивне и негативне стране људског карактера. Инанимантна антропосфера, као ресурс фигуративних значења у српском језику, веома је богата: реилексемама се именују не само физичке и карактерне особине човека, већ и облици његовог понашања, припадност одређеном друштвеном слоју, типичне социјалне улоге, облици испољавања психолошких стања и емоција, темперамент и духовност. Мислећи и говорећи о сегменту свог окружења који не поседује карактеристику хумано (па тиме и сему људско), без обзира на то припада ли или не припада свету живог / анимантног (уп. животиња, биљка, предмет, материја и др.), човек у свој систем вредности уводи све што га окружује; успоставља аналогије које се тичу форме, функције, позиције и сваковрсних потенцијала (нпр. 
квантитативних, кинетичких, структуралних и др.), а потом их продева кроз себи, тј. изворним говорницима једног језика својствену мрежу културних, социјалних, етичких и естетских критеријума. Зато семантичку деривацију утемељену на персонификацији и антропоморфизацији, као аналогним процесима, можемо схватити као језичку универзалију, док исходе ових компатибилних процеса - усклађене с културом и традицијом одређене језичке заједнице - треба сматрати (етно)специчностима „уграђеним” у поједине језике. Идентификација са неживим ентитетима даје слободу промишљања целокупног окружења тако што се поједини предмети, њихова структура, намена, материја(ли) од којих су саздани, начини примене, па и статус који је тим објектима приписан на основу употребне или које друге (нпр. симболичке) вредности много еластичније транспонују у духовни и културни живот човека, јер је човек креатор већине неживих ентитета (изузимајући материју која у природи постоји независно од њега; уп. дрво, камен, злато и сл.).

1.1. Припадност једном језику подразумева и припадност истој когнитивној матрици која укључује и сферу инанимантног као издашан ресурс аналогија са живим светом и хуманитетом који своју надмоћ, између осталог, показује способношћу да се удене у најразноликије облике постојања, да присвоји туђа и/или преда своја својства чак и несродним и појмовно удаљеним ентитетима. Из тако успостављених, универзалних кореспондентности произилазе ,аутопортрети” изведени аутохтоном, етноспецифичном палетом семантичке деривације усмерене на анимантне и инанимантне ентитете значајне за одређену језичку заједницу.

Особеност семантичке деривације реилексема видимо у удаљености изворног и циљног домена, која је у овом случају много већа неголи код зоолексема и фитолексема, јер симултани процеси персонификације, тј. антропоморфизације објеката (ствари и материје) и реификације хуманог домена подразумевају виши степен апстраховања и сложеније асоцијативне путеве. Поред тога, развој фигуративног значења реилексема укључује и софистицирану аутоконцептуализацију која, уз „знање о другом”, лежи у основи хомоцентризма Великог круга постојања.

1.2. Човек има изразиту склоност према антропоморфизацији, а то је лако запазити код деце, која су спремна да готово свим предметима и стимулансима из свог окружења припишу анимантност (исп. Епли и др. 2007: 870). Одрасли су, по свему судећи, мање склони оваквом начину размишљања, што Еплија и сараднике наводи на закључак да антропоморфизам, као функционална презентација селфа, варира током развоја, и то захваљујући знању које ce, приликом поимања не-људских ентитета, активира, примењује и прилагођава, а сваки део тог процеса може бити вођен и модификован мотивацијом за разумевање и ефективну интеракцију с другима; то показује да је искуствени сегмент знања неопходан предуслов антропоморфизације (исто, 878). Примећујемо да томе - као додатан услов - ваља придружити и финоћу структурисаности тих знања, јер само када су високоорганизована она могу с лакоћом бити активирана и након асоцијативног премошћавања подстаћи развој фигуративности реилексема. 
1.2.1. Човеков дух и језик оживљавају свет предметног тако што им приписују властита својства. Та појава позната је у онтогенези и у филогенези, а потврђују је дечји анимизам, али и широк хоризонт персонификације у народној и уметничкој књижевности. Дечји анимизам огледа се у веровању најмлађих да сви предмети имају особине живих бића, отуда деца играчкама, али и другим објектима с лакоћом приписују својства живих бића (уп. Моја лутка се љути / смеје / радује... и сл.). Инфалтилни анимизам и анимизам у бајкама имају заједнички именитељ: потребу за пресликавањем властитих особина, а затим и уверење у могућност комуникације с несродним ентитетима. Персонификацију, дакле, можемо посматрати као одраз и резултат тежње за комуницирањем, тачније за споразумом и хармонизацијом с окружењем. Поред тога што је потреба за персонификовањем израз хомоцентричности, она је и део природног процеса социјализације, без кога човеково биће, у потпуној изолованости, не би умело нити могло себе да сагледа, процени и дефинише. Из тог угла посматрајући персонификацију, као резултат двосмерних метафора унутар ВК, можемо рећи да је њој инхерентна тежња према приближавању, док је антропоморфизација логична допуна тог процеса у смислу изједначавања ентитета, пошто се без тог изједначавања не би могла успоставити концептуална равнотежа (нпр. не би се могло говорити о „продукцији, фабриковању високообразованог кадра и стручњака” као о производњи робе, нити о „свиленом голману” као о свиленој марами и сл.).

1.3. Домен инанимантног је у литератури, рекли бисмо, доста запостављен, мада је много богатији и занимљивији но што би се очекивало. Стога овај рад представља продужетак нашег интересовања за резултате процеса реификације у српском језику, ранијих разматрања концептуализације адјективних реификата и поимања човека и људског као објекта у српском жаргону (Вељковић Станковић 2018). Сада ћемо, поред семантичке деривације лексема којима се именују дискретни објекти, пажњу посветити изворним доменима материје, облика, деловања на предмете (манипулације и /пре/обликовања), служења предметима и сл.

Значај испитивања концептуализације реилексема у српском језику, али и свих других антропоцентрично усмерених фигуративних значења у оквиру Великог круга постојања, видимо у томе што нам оно омогућава идентификацију и детаљније сагледавање бихејвиоралних културема, тј. културноспецифичних чинилаца који се реализују у језику, представљајући својеврстан мост између културе и језика којим изворни говорници на когнитивном и вербалном плану артикулишу себи својствене вредности. Истраживање је ослоњено на корпус који чине дескриптивни речници српског језика (РМС, РСАНУ, РСЈ) и Корпус савременог српског језика Математичког факултета у Београду (СрпКор2013), а бави се метафтономијски утемељеним (само)идентификацијским процесима са светом инанимантног у српском језику. 


\section{2. Свет предметног у човековом оку, мисли и језику}

2.1. КОНЦЕП ОБЈЕКТА. Ствар je „,sve što materijalno postoji u širokom smislu" (Лалевић 2004, s.v. stvar; уп. РМС ствар 1. сваки предмет, производ било чега, било шта неживо што материјално или физички постоји), али се односи и на стања, ситуације, прилике у којима се штогод дешава (уп. Ево како тамо ствари стоје...), а фигуративно и на „оно што служи као извор каквих осећања, емоција; сама осећања" (РМC 4, s.v. ствар - Наташи [је] било непријатно што су се мијешали у њезину ствар љубави према кнезу Андреју. Крањч. Стј.). Тако, говорећи о стварима и објектима, говоримо о људском реалитету којим је увелико обухваћен човек као физичко, али и емотивно, духовно и друштвено биће; реификација је, дакле, делатна у свим сферама мишљења и говора (УП. УМ ЈЕ ТЕЛО; ИДЕЈЕ СУ ОБЈЕКТИ $\rightarrow$ УМ ЈЕ САДРЖАТЕЉ ОБЈЕКАТА, МИШљЕЊЕ ЈЕ МАНИПУЛИСАЮЕ ОБЈЕКТИМА, РЕЧ ЈЕ ОБЈЕКАТ / СТВАР, Лејкоф и др. ${ }^{2} 1991:$ 80, 94).

Виђење себе у неживом захтева добро познавање властитог бића, понајпре због несличности, али и због неопходности да се овакав концепт ослони на дубље разумевање неживог ентитета као изворног домена, што подразумева комплексне релације између форме, материје, садржине и суштине (сфере) предметног и (сфере) људског. Однос материје и форме Аристотел је посматрао с обзиром на појединачне ствари, као и с обзиром на међуодносе ових двају феномена, те је у свакој (појединачно) постојећој ствари видео каузалитет форме и материје, које једна без друге не могу постојати. Поред тога, овај велики филозоф је сматрао да се ствари могу сазнати кроз развој њиховог облика из твари (Узелац 2003: 129-131). Авицена такође сматра да су ствари одређене формом, те да суштину треба тражити у јединству материје и форме (Аквински 2010: 11-15).

У светлу нашег испитивања, примећујемо да се сличан саоднос може пратити и у језику, у коме, као „материја” с потенцијалом полсемантичког ширења, постоји лексички круг који денотира ствари; ствари, пак, подразумевају поседовање форме која се когнитивним спрегама доводи у везу са човековом „суштином”, што је услов за настанак фигуративних значења (тј. нових семантичких „садржаја”).

Премда нам није циљ исцрпно разматрање мисаоних поставки знаменитих филозофа, на ова промишљања скрећемо пажњу јер се она, сада више на (интуитивном) плану уметничких перспективизација, унеколико дају препознати и у књижевним делима, што нас упућује на општеприхваћене и свеприсутне релације живог и неживог у мисли и језику:

(1) Филозофи који тврде да ништа тако не живи, не говори и не осећа као што то чине мртве ствари, када би видели ове две куће, казали би да су зевале једна крај друге (СрпКор2013; Александар Дима, Четрдесет и пет витезова, књ. 2, превод А. М. Поповић, 1964).

(2) Одатле је дошло да се везујем, да сам се много везао за мртве ствари које за мене добијају важност бића и да ми кућа постаје, да је постала, свет где сам водио усамљенички и врло активан живот ок- 
ружен стварима ... мени присним и симпатичним као људска лица (СрпКор2013; Ги де Мопасан, Ко зна, Београд, Нолит).

(3) И док присуство моје мајке и моје сестре осећам као живот ... дотле смрт ствари у тој ноћи осећам скоро опипљиво, са неком болном тежином, јер то је само један од доказа више за постојање смрти... (СрпКор2013; Данило Киш, Башта, пепео, Београд, Службени гласник).

(4) Ко да изрази и пренесе (тако мисле они!) оне колективне дрхтаје који су одједном затресли масама и који су са живих бића стали да се преносе на мртве ствари, на пределе и грађевине? (СрпКор2013; Иво Андрић, На Дрини ћуприја).

Когнитивна активност тесно је повезана с употребом објеката свести (па тако успешан умни напор, човекову бистрину и луцидност сагледавамо као резултат примене оштрих, прецизних и ефикасних оруђа која схватамо као ,алате” мишљења; уп. РАЗУМ ЈЕ ОШТАР ОБЈЕКАТ, Лејкоф и др. ${ }^{2} 1991$ : 139), што се очитује у фигуративним значењима многих придева, али и глагола и именица (исп. РСАНУ: уп. оштроуман ${ }^{1}$; оштар 11. а. који се одликује продорним, пронииљивим умом, памећу, бистар, интелигентан, оштроуман; супр. глуn, туп; уп. бридак ум, мисао, реч; изоштрити се постајати проницльивиј, финији; оштрити 3. а. чинити оштроумнијим, способнијим за схватање и разумевање; уп. изоштравати ум, памет, мисао, дух; оштровидан б. оштроуман, довитљив, пронииљьи; оштроумац, оштроумник итд.).

На први поглед чини се да би очекивани исходи концептуализације човека као објекта недвосмислено водили поимању људског бића као инертног и статичног, јер је инанимантност инхерентно својство предмета, чија егзистенција, употреба, па и потенцијална мобилност зависе искључиво од људи као њихових креатора. Но, као што детаљнији увид у когнитивно саодношење ових несродних домена показује, појмовна реификација, на којој почива развој фигуративних значења лексема које денотирају предмете не утиче битно на снижавање или укидање динамичних својстава људског, и то из три разлога: (1) најпре зато што се квалитет објекта често посматра као (потенцијално) делатан када је у питању карактеризација човека (нпр. атрибуција особе придевима крхак, тврд, широк и сл. указују на подразумевани степен кохеренције или запремања простора преко којих се непосредно асоцира(ју) начин(и) понашања и делатног испољавања носилаца овако именованих карактерних особина; исп. Вељковић Станковић 2018: 209-219);

\footnotetext{
${ }^{1}$ Као синоним прид. оштроуман у српском језику постоји запостављен енантиосемичан адјектив танкоуман, чије примарно значење упућује на проницљивост, док му се секундарно супротставља: (уп. РМС, РСЈ) танкоуман 1. оштроуман, пронииљив, бистар: дечак. 2. плиткоуман, ограничен, туn: сабеседник. Енантиосемичност ове творенице видимо као резултат опозитне концептуализације квантитета (МАЛО / ТАНКО ЈЕ СЛАБО / ОСКУДНО / ЛОШЕ / ИНФЕРИОРНО : МАЛО / ТАНКО ЈЕ ПРЕФИЬЕНО / ДОБРО / СУПЕРИОРНО), која ј УПаДљИва код значења прид. танак (РСЈ: 3. фиг. а. мали, слаб /по количини и вредности/, сиромашан, оскудан /у битним квалитетима/) и прид. танан (РСЈ: 2. врло осетљив, нежан; истанчан, префињен, суптилан: бити танане природе; бити тананог духа).
} 
(2) други разлог тиче се облика употребе одређеног објекта који се непосредно повезује с типичним реаговањем или социјалном улогом особе (уп. марионета, играчка, машице и сл.); најзад, (3) изразиту динамику сличних метафоричких реализација откривамо код глагола којима се именују радње које се приписују човеку-објекту. Лексеме овог типа, генерално узевши, гранају се у два правца, (а) у смеру градње и (само)обликовања, који бисмо означили као (само)креирање (изградити /се/, изоштрити /се/ и сл.) и (б) у правцу деструкиије (уп. сломити, срушити, пући и сл.). Реификовано људско биће посматра се, дакле, као објекат манипулације, конструкције, реструктурисања и деконструкције, а оно при томе може бити објекат, субјекат деловања или носилац обеју функција истовремено (аутокреација : аутодеструкција). Зато као резултат метафоричког и метонимијског постваривања хуманог (уп. барјак, перо, перјаница и др.) посматрамо лексеме којима се именују целовити објекти (именице), материја (земља, камен, рђа), квалитети материјала приписани реификованом објекту (завезан, закренут), специфични облици, садржатељи (ћошкаст, шупаљ, празан) и речи које оцртавају радње и процес(е) чији је типични објекат предмет (наоштрити се, скресати, изрибати и сл.). У многим случајевима реификација се јавља код семантички и творбено повезаних лексема (уп. хладан, охладити се; експлозиван, експлодирати), али тада, као и када су у питању конверзија (прид. отворен, прил. отворено) и деривација (уп. РСАНУ: камен 1. в. фиг. особа чврстог, постојаног карактера. г. фиг. неосетљива, хладна особа; каменица 6. фиг. а. (ж и м) погрд. човек који ћути као камен; каменити се 2. фиг. а. постајати непомичан, непокретан, као без живота. и сл.), фигуративна значења остају у оквирима исте когнитивне матрице.

Материјално окружење зато сагледавамо као веома широк и захвалан изворни домен чија перцептивна доступност омогућава испитивања заснована на непосредном искуству, што олакшава посматрање путева утеловљавања. Наиме, типичан предмет је материјална појава у простору и времену (исп. PMC, s.v. предмет), тродимензионалан, нежив ентитет, чулно опажљив, операбилан, саздан од материјала одређених карактеристика, једноставан (монолитан) или сложен (вишеделан) и непокретан, већином зависан од човека (или човеку намењен). С друге стране, човек је живо, разумно, друштвено биће које поседује емоције, способност говора, стварања (социјалних, културних и др. добара), људи се у свом делању руководе властитом вољом и носиоци су различитих карактерних и моралних особина. Човек је истовремено типични корисник и креатор предмета, и то му, упркос удаљености од домена неживо, даје повлашћену улогу сувереног концептуализатора.

Управо човекова потреба да разуме властиту природу активира реверзибилне метафоричке споне са свим изворним доменима обухваћеним Великим кругом постојања. Када је у питању карактеризација, те споне морају „отеловити” његове особине које припадају домену апстрактног, те је пут концептуализације најпре утрт општом метафором ЧОВЕК ЈЕ ОБЈЕКАТ, преко које се „материјализују”, тј. реификују и људска осећања, активности, облици делања, па и етичке вредности, нпр. преко метафоре чистоте (блато, 
каљуга, глиб) и помоћу сликовне схеме вертикалности (Расулић 2004: 215) (исп. ниже 2.5, врх : дно).

2.2. КОНЦЕПТ МАТЕРИЈЕ. Личност се посматра као материјал (Лејкоф и др. ${ }^{2}$ 1991: 209), а особине као својства материје (уп. мек, крут, тврд и др.). Отуда је разложно поћи од библијске метафоре ЧОВЕК ЈЕ ЗЕМЉА, коју препознајемо у једном од значења им. земља (РСАНУ: земља 3. а. фиг. нар. земаљско, смртно створење, биће које ће се и само претворити у земљу). Пословица Земља по земљи ходи, коју бележи Вук, сведочи о дубини и чврстини каузалних (и судбинских) веза између људског и материјалног. Социјалне и моралне вредности такође се очитују у фигуративним значењима различитих облика материје, а међу њима није мали број оних којима се маркира отпадништво због припадности нижем, потцењеном слоју (шљљм, мутљљаг, талог); стигматизованости се придружују морална и духовна маргинализација (РСАНУ: каљуга 2. фиг. беда, духовна, морална прљавштина, гадост; одвратност). У овој лексичкој подгрупи најразуђенију негативну фигурацију има им. блато, којом се именује изопштена друштвена група (6. фиг. олош, ильам), најнегативније особине те групе (7. фиг. а. поквареност, развраћеност), удес и стање оних који се налазе у незавидном положају (7. б. тешко стање, беда, понижење), али и срамно вербално понашање (8. фиг. ружне речи, измииљотине, клевете).

Одбојност према таквој материји, па самим тим и према човеку коме се слична својства приписују може се односити не само на одсуство чистоте (нпр. окаљан, укаљан, облаћен; уп. НЕМОРАЛ ЈЕ ПРЉАВШТИНА : МОРАЛНОСТ ЈЕ ЧИСТОТА, Лејкоф и др. ${ }^{2} 1991:$ 186), већ и на лоше структурне и непријатне тактилне особине (нпр. љига, љигав, љигавац = онај који је љигав, нестабилан, несигуран, неодређен /у погледу карактерних особина, достојанства, поноса/; исп. РСАНУ).

Општа метафора квантитета (ВРЕДНО ЈЕ ВЕЛИКО) управља асоцијативним процесом који недостатак или смањивање квантитета маркира као негативну појаву (исп. плитак, тесан, ускогруд и сл.; Вељковић Станковић 2018: 215-216), па отуда, у складу с деловањем, метонимијом начин деловања материје за начин човековог понашања добијено је значење им. стипса = ичиција, икртац, тврдица (РМC). Позитивне стране наглашене кохерентности (чврстине) испољавају се јасније приликом спецификације материјала који се, поред тврдоће, одликују и несавитљивошћу, а пре свега издржљивошћу. Тако именице камен, челик, кремен² и сл. и од њих изведени придеви и

\footnotetext{
${ }^{2}$ Овде наводимо само основна и она фигуративна значења речи која се односе на човека како их доносе велики описни речници српског језика. РМС: челик 1. гвожђе, железо велике тврдоће која се постиже додавањем нешто угљеника, сумпора и фосфора, надо, оцал. 3. фиг. онај који је чврст, јак, издржљив; јунак. - Оно што је у гору отишло, оно је челик, оно су срца што не могоше трпети неправду. Вес. 4. (у атрибутској служби) челичан, чврст, отпоран, постојан, издржљив: човек. РСАНУ: кремен 1. мин. а. врста камена, минерал стакластог сјаја и велике тврдоће ( $\left.\mathrm{SiO}_{2}\right)$, квари. 2. фиг. (у истицању физичких и карактерних својстава) а. онај који је чврст, отпоран, јак; отресита, сналажљьва, брза, ватрена особа. - А како ми се чини отресит је момак. - Прави кремен! ... Што уради оно ти је ... свесрдно урађено (Глиш. 1, 109). б. онај који остаје при својој речи, одлуци и сл., онај који је непоколебљива, несаломљива врста карактера. - Као, море! Ватра! Кремен! Челик карактер (Срем. 15, 14). 3. (у атрибутској служби,
} 
глаголи (уп. прид. камен, челичан; гл. челичити /се/), у складу с перцепцијом и богатим искуствима које човек има с овим материјалима, апострофирају постојаност и отпорност, особине цењене уколико се тичу деловања у социјалном окружењу (храброст, одлучност, издржљивост и сл.), али и када је у питању физиолошко обележје. У непрекидној борби за опстанак ове карактеристике се додатно промовишу, што потврђује да су појмовне метафоре, не само оне универзалне (ЕНТИТЕТ X ЈЕ ЕНТИТЕТ Y), већ и специфичне, које се тичу разумевања посебних људских својстава (ЧОВЕК ЈЕ МАТЕРИЈА Х), у једнакој мери културални и когнитивни ентитети и процеси.

Слаба структура материје доводи се у везу са недостатком снаге, нејакошћу физикуса и карактера (уп. РСАНУ: пекмез 2. а. слабашна, нејака особа, слабић, мекушач /и у физичком и у карактерном смислу/. б. размажена особа /обично дете/; пекмезар 2. подр. безначајна, неугледна особа; особа која живи на туђ рачун; пекмезаст слаб, нејак, размажен; пекмезенко особа без воље, одлучности и сл., слабић, мекушаи). Чак и када је у питању цењена, фина материја пријатна на додир, поред позитивних значења (уп. РМС свилен в. пријатан /о гласу/; РСЈ: фиг. пун обзира, мек, питом: човек ), управо због недостатка чврстине залази и у домен непожељног (РСЈ: слабе физичке издржљьиости, неотпоран; уп. РМС свилењак 2. фиг. онај који је одрастао у удобности и богатству, размаженко).

2.3. КОНЦЕПТ ФЛУИДА. Концепт материје обухвата и концепт човека као флуида, који се имплицитно најчешће спецификује као вода, премда ова именица нема фигуративно значење које би упућивало на човека. Но, будући да се различите емоције схватају као флуиди у човеку као садржатељу (уп. Преплавила ју је љубав / нежност / туга. Прокључао је од беса / гнева. разг.), немали број глагола и придева, већином девербала, упућује на то да човека поимамо и као садржатеља флуида (уп. узаврети, узбуркати се, смутити се, сјезерити се; бистар, мутан, смућен, помућен, узбуркан и сл.). Својим особинама (бистрином, животодавношћу, могућношћу промене агрегатног стања), а пре свега динамиком, тј. експанзивношћу и снагом специфичним за водену стихију (реку, море) метафора воде, као прототипичног флуида, покреће многа фигуративна значења у којима откривамо природу човека, понајпре његову емотивну и духовну страну.

У складу с поимањем емоција као флуида, о неочекиваном, наглом показивању унутрашњих преживљавања и њиховој вербализацији говори се као о прекорачењу граница садржатеља (речног корита или какве посуде). Тако су, на пример, значења глагола излити (се) (отворено показати, открити /pacположења, мисли/) и искипети (ражестити се; истрошити се, исирпсти се

као први део неправих сложеница) постојан, издржљив, храбар; окретан, брз, вредан. - Ранко је био кремен дете. Био је руку чистих као злато, а вредан као кртица (Дач. Ж. 2, 44). камен 1. а. мин. минерални агрегат различитог састава од кога се великим делом састоји Землина литосфера, стена. в. фиг. особа чврстог, постојаног карактера. - Никад ниси могла чити да сам те ја гдје оговарао, а видио сам ја много ... Али ја сам камен (Шим. 6, 34). г. фиг. неосетљива, хладна особа. - па добро ... и ја нисам камен, мислим и ја на све то (Вас. Д. 2, 111). фиг. тешка брига, невоља, мора. - А мени је камен на души ... Теби ћу ево ... казати: гризем се што никако не могу да се спремим за оно што ме чека (Сек. 5, 197). 
/од болести/) обликована метафором ПОКАЗИВАњЕ ОСЕЋАЊА / МИСЛИ ЈЕСТЕ ИЗЛАЗАК ФЛУИДА ИЗ САДРЖАТЕЉА. Немир и узбуђење такође се поимају као бурни покрети водене масе (уп. узбуркати се, узаврети $=y_{3}$ будити се, ускомешати се), док се обрнути процес сагледава као мирна вода (језеро) (уп. РМС: сјезерати се / сјезерити се = смирити се, стишати се).

Аналогно емотивнима, и ментални човекови потенцијали за изворни домен имају воду. Под окриљем метафора РАЗУМЕВАњЕ ЈЕ ВИЪЕЊЕ и ИДЕЈЕ СУ ПЕРЦЕПЦИЈА оштроумност и способност логичког мишљења разумевају се као „прозирање”; виспреност се схвата као бистрина (уп. бистар човек), а пометеност мисли и речи види се као на смућеност (уп. РМС смутити се 4. а. доћи у стање збрке, пометености. б. збунити се, смести се, осетити се нелагодно. в. узнемирити се, узрујати се, узбунити се.). Концепт флуида такође обликује и фигуративна значења глагола којима се именују човекови когнитивни капацитети и физиолошка стања, о чему сведоче гл. изветрити, исхлапити (РСАНУ: 2. постати старачки слаб /најчешће у духовном смислу/, изнемоћати, посенилити) скопнети и ископнети (РСАНУ: 3. фиг. изгубити снагу, свежину, оронути, смршати).

С друге стране, промена агрегатног стања, у зависности од висине температуре којом је условљена, може (последично) подразумевати деловање изразито негативних (следити се) или пожељних емоција (уп. истопити се), па се метонимијска потка учинак топлоте / хладноће за емотивну реакиију и степен топлоте за темперамент доводи у непосредну везу с одређивањем човека као топлог (РМС: 3. а. који изражава саосећане, наклоност, срдачан. в. пун осећања, нежан) или хладног (3. б. равнодушан, неосетљив, нељубазан):

(5) Био је топао и љубазан према нама и споразумевали смо се на француском (СрпКор2013; www.rts.rs, 29. 1. 2010).

(6) Целе те ноћи окретало се то невероватно коло уокруг, у његовој средини био је ритмајстер, хладан, неумољив; сам непомичан и нем, он није дао никоме да мирује и ћути (СрпКор2013; Иво Андрић, На Дрини ћуприја).

(7) Гануо ме је њен поглед, топао и хладан истовремено (СрпКор2013; Драгана Великић, Руски прозор, електронска верзија).

2.4. КОНЦЕПТ ВАТРЕ. Концепт ватре у српском језику изразито је динамичан; у њему се огледају најживље активности подстакнуте животним страстима, снажном жељом и мотивацијом. Како се човек схвата као садржатељ емоција, од којих се многе схватају као ватра (уп. љУБАВ ЈЕ ВАТРА, ЉУТЊА ЈЕ ВАТРА, ТУГА ЈЕ ГОРЕЊЕ, БЕС ЈЕ ВАТРА; исп. Драгићевић 2010: 157, 165, 180, 200), нема сумње да топлоту, ватру и процес горења треба уврстити у концепт људског бића обухваћен материјом, јер без материје нема ватре. Метафора ватре у српском језику често има позитивне исходе, нарочито када се посматра као извор животодавне топлоте; тада јој се приписују енергија, полет и крепкост, док се њено одсуство изједначава с губитком 
виталности (СТРАХ ЈЕ ХЛАДАН, исто, 190). Отуда лексема ватраз окупља значења усмерена на човека у којима се огледају најразличитији облици агилности, силине осећања и живости делања (страст, занос, одушевљење, храброст, духовна снага, али и оштрина критике, гнев, јарост), а будући да се асоцијативно повезује са сјајем, бодрошћу и брзином, таква слика опстаје и у одсуству пламена, што се огледа и у значењима им. жар 2. фиг. одушевљење, усхићење, занос. 4. сјај (обично у очима) (РМС).

Енергија топлоте и светлости у придевима запаљив и горљив (запаљив 2. фиг. који се лако, брзо одушевљава, загрева за нешто, распаљује због нечега; горљив 2. фиг. а. ватрен, одушевљен. б. ревностан, вредан. в. пожртвован, самопрегоран) очитује се као максимална динамика духа (одушевљење, усхићење, занос; уп. ИНТЕНЗИВНЕ ЕМОЦИЈЕ СУ ТОПЛОТА, Лејкоф и др. 21991: 143), а тако је и код већине глагола горења (исп. ниже А), код којих семе топлоте, силине, животности и светлости сједињују полет телесног и духовног у човеку. За разлику од њих, глаголи гашења (Б) постављени су опозитно, па се кроз наглашено одсуство поменутих сема (топлота -, cuлина / животност -, светлост -) као заједнички именилац јавља нестанак (виталности), те се обе семантичке групе могу сматрати репрезентима контрастно постављених континуума топло - хладно, силно / животно / светло - немоћно / неживотно - мрачно (УП. СВЕТЛОСТ ЈЕ МАТЕРИЈА + / ДОБРО $\rightarrow$ живо, динамично : ТАМА ЈЕ МАТЕРИЈА - /ЛОШЕ $\rightarrow$ неживо, нединамично).

A.

РСАНУ: запалити 2. фиг. учинити, утицати да се нешто развије, распали, разбукти. б. одушевити некога за нешто, привући, придобити. - Њена појава опчинила је краља Лудвига I и окренула га демократском уређењу ... запалила је једну групу универзитетских младића који су у њој гледали симбол правде и слободе (Глиг. 1, 193). 2. фиг. в. одушевити ce, загрејати се за нешто, бити понет нечим. - Ми [смо] Словени па брзо гаснемо, као што смо се брзо запалили (Крл. 1, 10).

изгорети 2. за истииање интензитета неког осећања (страсти, жеље, стида и сл.). - Кад нисам код ње, да изгорим жив од жеље да је видим (Стер. 12, 189).

изгарати 3. фиг. а. бити обузет каквим великим осећањем, каквом великом страшћу. - Његово срце изгара од весеља (Коз. Ј. 2, 39). б. жудети за неким или нечим. - Не можеш ти онога мрзети који толико за тобом изгара (Вин. 3, 160). 4. фиг. радити неуморно, с пуном преданошћу, не штедећи себе. - Успут су ми рекли да је вриједна ... и да изгара на народном послу (Шуб. 4, 110).

${ }^{3}$ У РСАНУ читамо: ватра 1. а. запаљена материја кад горећи развија топлоту и светлост, огањ. 2. боја ватре, румен, руменило (на лииу). 4. а. повишена телесна температура, бунило. б. телесна, животна топлота. - Ухватила га за руку, која је горела последњом ватром (Живад. 2, 7). 5. фиг. писмени или усмени напад, грдња, оштра критика. 9. а. страст, страственост, љубав, љубавна жудња; жар. б. занос, одушевљење. 10. а. љутња, гнев, јарост. б. жучност. в. силина; жестина; ватреност. г. жив темперамент. 12. храброст, смелост, одважност; надахнуће, духовна снага, инспираџија. - Он осети у себи ватру која човека извештава о богоданом дару; и тако поста појета (Мил. М. Ђ. 17, 195). 16. (у придевској служби) који у великој мери има неку особину а. веома вредан, жустар, хитар (на послу). - Беше ватра за работу ... вредна ... ради и све поје ... волешем гу, кад потрчи! (Срем. 8, 155). в. одважан, куражан, храбар (човек, јунак). г. кочоперан. д. веома привлачан, заносан. - Обично је озбиљна, фина као у салону, данас врагољаста, ватра (Шен. А. 4, 67). 
РМС: разгрејати 2. фиг. испунити пријатним осећањем, орасположити; привући, заинтересовати. - Његове ју ријечи разгријаше. Кум. разгрејати се орасположити се, развеселити се под дејством алкохола. 2. фиг. пасти у ватру, одушевити се, занети се. - Фехим се био разгријао, узнио - а младићи су га слушали позорно. $O-A$.

Б.

РСАНУ: згаснути 3. фиг. б. престати живети, умрети. - Четврт сата ... прије но ће згаснути на својој таваници, Зимко је ... мислио на добру вечеру (Михал. С. 1, 19).

РМС: сагорети фиг. пропасти од претераног напрезања, од напорног рада или од тешке болести. - Његов живот [je] сагорео на раду пре времена. Бел.

угасити 2. фиг. б. смирити, стишати (гнев, бес, јарост). 4. разг. зло проћи, пропасти.

утулити се 1. престати горети или светлети, угасити се. - фиг. Она ће изгорети сама у себи, утулити се као остављена светиљка. Сим. 2. фиг. нестати, изумрети, искоренити се. - Код краљева њиних утули се раса, стара смелост њина нестаде тог часа. Панд.

утуљено прил. без сјаја у очима, мрачно, безизражајно, тупо, угашено. - Гледао је уморно, тупо, утуљено. $C u j$.

2.5. КОНЦЕПТ САДРЖАТЕЉА. Поимање човека као садржатеља незаобилазно је приликом разматрања концептуализације емоција, које разумевамо као флуиде, жива бића (човека, животињу, биљку), (нат)природне силе, а такође и као (операбилне) објекте који се могу давати, узимати, изгубити, наћи и др. (уп. Драгићевић 2010, Перез Рул 2001/2: 183-184). Поред квалитета садржатеља, важни су облик садржатеља и степен његове испуњености. Отуда, иако прид. празан означава духовну ограниченост, прид. пун не може се сматрати правим опозитом у смислу процене духовног садржаја, јер испуњеност може упућивати на оптимално присуство позитивних, али и негативних садржаја, тј. емоција, расположења и сл. (нпр. човек пун радости, cpeће / туге, бола; пун доброте / злоће и сл.). Ипак, испуњеност и пуноћа говоре у прилог постојању и реализацији капацитета личности (духовних, емотивних и интелектуалних; нпр. пун идеја), што доприноси да се овај квалитет чешће убраја у оне који су пожељни (в. 2.9.2).

Поред постојања садржаја, важне компоненте су видљивост и доступност, које се опојмљују преко концепата отворености и затворености ${ }^{4}$, који се пре свега односе на осећања и духовни „простор”, а с тим у вези и на слободну вербализацију емотивних стања у непосредној комуникацији, и на социјалну улогу коју такво понашање обликује (уп. закопчан):

(8) Она сасвим друге нарави. Отворена, говорљива и насмејана (СрпКор2013; Саша Божовић, Теби, моја Долорес, Београд: Четврти јул, 1984).

\footnotetext{
${ }^{4}$ Ови концепти лако су препознатљиви у значењима антонимних придева отворен и затворен (РСАНУ: отворен 8. а. који нескривено исказује своје ставове, осећања и др.; који није уздржан, који се без устезања, радо поверава, искрен. б. својствен таквој особи, који јасно, нескривено одражава јасна расположења, неприкривен. д. (често у ген. синтагмама, уз им.: глава, памет, разум, дух и сл.) уман, разуман, пронииљив, бистар. 9. а. који делује јавно, неувијено. б. који се не скрива, не прикрива, који се показује, испољава отворено, нескривено, неприкривен, јасно изражен, испољен. затворен 2. а. који не открива своја осећања и расположења, који се нерадо поверава, закопчан, уздржан. б. на којему се не огледају осећања, расположења, промене у њима, непрозиран, недокучив; непредусретљив, резервисан).
} 
(9) После пола сата ми углавном знамо животе један другога; сваки је отворио своје срце како у цивилизованом свету није чак ни ред отварати (СрпКор2013; Растко Петровић, Африка, Београд, Нолит).

(10) Мој дух, затворен у себе, постао је доступан осећању захвалности, сласти заједничког нежног живота (СрпКор2013; Јан Потоцки, $P y$ копис нађен у Сарагоси, Београд: СКЗ, 1988).

(11) Њена суштина затворила се у себе попут шкољке (СрпКор2013; Момо Капор, Зое, Загреб: Знање, 1984).

(12) Док је пре преображаја закопчан био као неко ко осим немоћи нема шта да крије, сада је то као неко ко моћ неће да показује (СрпКор2013; Борислав Пекић, Нови Јерусалим, електронска верзија).

(13) Никада дотад закопчани професор Тарановски није био тако говорљив (СрпКор2013; Миодраг Поповић, Великани старог Филозофског факултета у Београду, у: Политика, 10. 10. 2001).

Позиција у садржатељу, нпр. врх, дно, сагласно оријентационим метафорама ДОБРО ЈЕ ГОРЕ и ЛОШЕ ЈЕ ДОЛЕ, користи се за представљање друштвене хијерархије, а на исти начин - према својој типичној позицији - концептуализује се и материја (уп. РСАНУ: кајмак 2. фиг. горњи друштвени слој, сталеж. РМС: талог 2. в. нижи, декласирани друштвени слојеви, људи са друштвеног дна, олош, полусвет). Међутим, концепт дна није једнообразан, што се огледа у битно различитим фигуративним значењима ове лексеме. У првом случају семантика је детерминисана схемом (социјалне) вертикале, док је, из другог угла гледано, иста позиција схваћена као повлашћена и скровита, па зато резервисана за најдрагоценије. Значајно се опажа као физичка особина, а њена важност сигнализована је средишњим местом (уп. срце, душа) и позицијом која обезбеђује заштиту - унутрашње и дубоко (УП. ЗНАЧАЈ ЈЕ ФИЗИЧКО СВОЈСТВО, ЗНАЧАЈ ЈЕ ВЕЛИЧИНА, ИсП. Лејкоф и др. ${ }^{2} 1991:$ 13). Отуда им. дно у домену људско развија значење 'најтананији, најдубљи део (душе, срца, бића и сл.)' (s.v. дно, РСАНУ 6), а такође и као 'основа, бит, суштина' (s.v. дно, РСАНУ 7). Унутрашњи човеков свет концептуализује се, дакле, као тродимензионални простор, а духовно средиште схвата се преко значајности положаја објекта у том простору (уп. прим. из РСАНУ: Закопао је спомене на најдубље дно себе, наваљао гломазно камење заборава (Симић Н. 4, 23).).

2.6. КОНЦЕПТ (И)РЕГУЛАРНОГ ОБЛИКА. За пометеност и збуњеност, као и за сва слична стања и манифестације несналажљивости и неналажења начина од стране појединца да се адекватно постави и/или реагује у каквој ситуацији, нема погоднијег изворног домена од ирегуларног облика предмета, којим се сликовито успоставља аналогија између хаотично постављене предметности и „облика” човекових лоше артикулисаних реакција. Метафора ирегуларности (ИРЕГУЛАРНА СПОљАШЊОСТ, тј. ФОРМА / ОБЛИК ЈЕ ИРЕГУЛАРНА НУТАРЮОСТ /ДУХОВНО СТАҢЕ/) оПонира метафори канонског облика и хармоничности (уп. бити уравнотежен : изгубити равнотежу), а већи број глагола и од њих изведених придева показује широк 
дијапазон дисторзија које се повезују с различитим типовима неспретности у понашању (вербалном и невербалном): Спетљао се, па све нешто мрси и завијено говори, рек'о би човек да је смотанко, срећом, није увек такав. (разг.) и сл.:

(14) ...оженио се најзад овде и времешан момак, за кога се сматрало да је некако уврнут, донекле ишчашен... (СрпКор2013; Политика, 17. 1. 2001).

(15) Некада анатемисани као смотани и невешти, људи који пишу и већину послова обављају левом руком... (СрпКор2013; rts.rs, 12. 8. 2008).

Несумњива афирмација регуларног облика и става, када је у питању човек, али и све што га окружује, огледа се у изједначавњу аномалне форме с мање или више озбиљним недостацима који су социјално непожељни (закренут = својеглав, на своју руку; уврнут = чудан, настран; сулуд. и сл.).

Промена форме (отупети, уоштрити се, укалупити се и сл.), као и модификација структуре (омекшати, смекшати, отврднути, углачати се и др.) упућују на реакције које су резултат социјалног и емоционалног прилагођавања. Истовремено, метонимија промена форме за промену понашаға / испољавања настанак фигуративности ових лексема доводи у посредну везу с метафором ЧОВЕК ЈЕ МАТЕРИЈА, јер је материја оваквим (пре)обликовањима подложнија од структурно дефинисаних предмета које је теже преобликовати. Зато се у потоњим случајевима, посебно када су промене нагле и/или драстичне, место модификације јављају последице деструктивног деловања: сломити се, урушити се, (пре)пући и сл. (ЧОВЕК ЈЕ ПРЕДМЕТ САЧИҢЕН ОД СОЛИДНОГ / ЧВРСТОГ МАТЕРИЈАЛА), Па се нарушавање првобитног облика доживљава као уништавање целине, а не као пука промена структуре (ПСИХОЛОШКО / ЕМОТИВНО ОШТЕЋЕЮЕ ЈЕ ФИЗИЧКО ОШТЕЋЕЊЕ (КАО ПОСЛЕДИЦА ДЕСТРУКТИВНИХ СИЛА) $\rightarrow$ кидати се, распасти се и сл.).

(16) Проблеми га нису сломили... (СрпКор2013; Политика, 8. 3. 2006).

(17) То што ја сваки дан долазим подигнуте главе на посао не значи да нисам изнутра сав искидан... (СрпКор2013; Политика, 22. 9. 2000).

(18) Али, још много пре жене поклекао је и сломио се мушкарац... (СpпКор2013; Политикини културни додаџии 2000).

Карактер се посматра као облик / форма (jep се сматра да га је могуће разумети посматрањем начина, тј. облика понашања), те је у овом изворном домену активна метафора ПРОМЕНА ФОРМЕ ЈЕСТЕ ПРОМЕНА САДРЖАЈА, тј. СВОЈСТАВА, а следствено њој и ОБЛИКОВАЮЕ ЉУДСКОГ КАРАКТЕРА ЈЕСТЕ ОБЛИКОВАЮЕ ПРЕДМЕТА (УП. избрусити се, УоблИчити се, тесати = формирати, обучавати, васпитавати; привикавати културним навикама). 
Најзад, човек концептуализован као солидан (компактан) објекат може, осим промени облика, бити подвргнут промени канонске позиције, што се на појмовном плану испољава као губитак равнотеже: узљуљати се, уздрмати се, срушити се и сл.

(19) Он је угрожен, али му дух није уздрман, он се не распада у парампарчад... (СрпКор2013; Раде Кузмановић, Дан и ноћ, Београд, 1993).

(20) ...наше осећање идентитета озбиљно је угрожено и ми се морамо бранити како би се пољуљана равнотежа личности опет како треба успоставила (СрпКор2013; Владета Јеротић, Човек и његов идентитет, Београд: Ars Libri, Земун, 2007).

Глаголи и девербативни придеви (пољуљан, уздрман, срушен и др.) не јављају се само као декриптори психичких стања и човекове социјалне позиције, већ се употребљавају уз апстрактне именице којима се именују друштвено релевантни односи и вредности (уп. пољуљано поверење / пријатељство; уздрман ауторитет / стандард; срушена нада / вера итд.). Отуда можемо закључити да су метафоре конзистентности (исп. Вељковић Станковић 2018: 216-217, фн 84) и стабилности неизоставан део концепта здравог духовног стања појединца и добро утемељених друштвених вредности.

2.7. КОНЦЕПТ СЛОЖЕНОГ ОБЈЕКТА. Објекти једноставне структуре, већином они који се убрајају у потцењену предметност, веома често

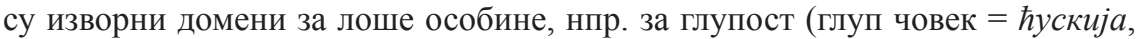
буздован, батина и др.) и у књижевном језику и у жаргону (уп. Вељковић Станковић 2018: 234). Ово, међутим, не значи да сложени, полифункционални објекти имају повлашћено место када је у питању карактеризација човека. Као што фигуративна значења именица с оваквим референтима показују, за именовање људског својства бира се, по правилу, једна карактеристична особина, али не обавезно према критеријуму престижности, нити пожељности (уп. аутомат фиг. онај који без размишљања врши наређења; марионета фиг. особа, лице које служи као оруђе у туђим рукама, којим управља други. и сл.). Ипак, структурна сложеност дозвољава да се објекат посматра из различитих углова, па није необично да такве лексеме развијају и по неколико - понекад доста различитих - фигуративних значења. Такав је случај с им. лутка, чији је фигуративни опсег одређен (а) семом лепо у позитивном смислу, (б) семом лепо у негативном смислу (физичка лепота за одсуство других квалитета) и (в) семом операбилно у негативном смислу (операбилност за одсуство воље, духовне и социјалне аутентичности):

РСАНУ: лутка 3. фиг. а. лепа, дотерана женска особа; у пеј. значењу: уопште особа без правих, обично духовних вредности, празна, испразна особа. б. особа која се поводи за другим, којом други управља; особа која служи као оруђе у спровођењу туђих намера, играчка, марионета, пион.

лутак ${ }^{1}$ 2. фиг. а. гиздавац, кицош, фићфирић, помодар. б. мушка особа која се поводи за другим, којом други управља, која служи као оруђе у спровођењу туђих намера, марионета, пион. - Одмах позна, шта су наумили ... | Власт краљеву да преузму на се, | А од краља да начине лутка (Новић 5, 52). 
PCЈ: лутка 2. фиг. а. (и хип.) назив од мила за дете, девојку и сл. б. лепа, дотерана женска особа. в. пеј. особа без правих духовних вредности, празна, испразна особа. г. особа која се поводи за другима, којом други управља; особа која служи као оруђе у спровођену туђих жеља, намера, играчка, марионета, пион.

лутак 2. фиг. гиздавац, кицош.

Као што се из наведених лексикографских дефиниција може видети, семантика им. лутка се шири, диференцира а истакнутија експресивност је јасније и оштрије поларизована (хип. : пеј.), док се полисемантичко поље им. лутак сужава, те РС бележи само једно фигуративно значење, што показује да је - осим изостанка пејорације - сема операбилности с временом избледела и да би се у неком савременом тексту, у контексту сличном оном који је наведен у РСАНУ (Новић) употребили синоними марионета, пион или сл.:

(21) Наиме, у „Невидљивима” уметници постају марионете у рукама неких скривених „инжењера душе” (СрпКор2013; Политика, 10. 7. 2008).

(22) Калмиков рече: „Ми смо у ствари пиони на шаховском пољу, а пиони не знају где ће их метнути играчева рука...” (СрпКор2013; Михаил Шолохов, Тихи Дон, превод Милоша Московљевића, Београд: Просвета, 1974).

Да примарну улогу у успостављању аналогија између сложених објеката и човека имају најистакнутија својства показују и именице из домена грађевине и делова грађевине (уп. стуб, стожер и сл.), посебно када су у питању објекти који денотирају трошан, оштећен грађевински објекат (метафора ЧОВЕК ЈЕ ГРАЂЕВИНСКИ ОБЈЕКАТ очитује се и код глагола: срушити /се/, обрушити се, поткопавати, руинирати; градити се, изградити се, уградити се и сл.):

(23) Иако је Божич, сад, био само руина оног Божича, он је, у Бечу, још увек, имао приступа у друштво својих некадањих другова... (СрпКор2013; Милош Црњански, Друга књига сеоба, Антологија српске књижевности, Учитељски факултет).

(24) То више није био млад човек, већ читава рушевина младости што се одржава и изванредном жилавошћу, и тесним дебелим омотима око бедара (СрпКор2013; Растко Петровић, Африка, Београд: Нолит).

(25) Патријарх Павле је сав свој живот посветио служби Богу и своме роду и себе уградио у живот наше цркве и нашег народа (СрпКор2013; rts.rs 15. 11. 2009).

(26) Изградио се у особу која, без икакве одступнице, себе увек даје до краја (СрпКор2013; Полтика, 31. 12. 2006).

2.8. КОНЦЕПТ МУЗИЧКОГ ИНСТРУМЕНТА. Код лексема с архисемом музички инструмент фигуративност је већином подстакнута асоцијативним везама са човековим говором, при чему преовлађује запажање непожељних облика и начина изражавања, као и непријатна акустичка сензација којом је говор праћен. Тако су чак и гусле, као инструмент уз који су наше 
епске песме (c)певане, те је стога стекао статус значајне културеме, посматране из угла снижене динамике, за епику својствене дигресивности и облика стилизације који подразумевају различита понављања, у деривату гуслати развиле пејоративно значење (гуслати пеј. разг. стално понављати, говорити једно те исто; зановетати; уп. РСЈ и РМС). Занимљиво је да таква семантизација, коју наведени глагол данас има у разговорном језику, изостаје у РСАНУ, што показује не само еволуцију значења ${ }^{5}$, већ имплицитно и њене узроке, који, претпостављамо, корен имају у губљењу афинитета за певање и слушање народне поезије у пратњи гусала, па и у постепеном удаљавању од традиционалних вредности. Веома сличну семантику развија и гл. гудети 1 (РСАНУ: 3. фиг. б. говорити, причати; понављати једно те исто /усмено или писмено/), којим се именује свирање на било ком гудачком инструменту (РСАНУ 1. б. производити звуке, мелодију /о гудачким инструментима/); зато бисмо рекли да се детериорација у овом случају (3. фиг. б) односи пре свега на неумешно свирање и непријатан звук који се притом производи, а не на одбојност према гудачким инструментима уопште.

Финоћа и квалитет звука доводе се у везу с лепим, разговетним и смисленим говором преко метонимије акустичке особине инструмента за квалитет казивањ $а$, па се сваки облик непримереног и нелепог језичког испољавања сагледава као какофонија произведена (зло)употребом каквог једноставног, обично потцењеног инструмента (уп. РСАНУ: дромбуљати 2. фиг. подр. а. говорити којешта, лупетати; дрндати 2. б. жаморити, жагорити; говорити којешта, наклапати, торокати; гунђати, чантрати; дрндало 2. разг. брбљива особа, наклапало. и сл.). Сувишним и одбојним сматра се неумесно понављање без размишљања (уп. РСАНУ: верглати фиг. лако и брзо нешто говорити /наизуст, не мислећи и сл./; верглаш фиг. онај који говори брзо, не мислећи), а посебно неумереност у говору, брбљивост, која се такође повезује с иритантним звуком различитих справа (уп. клепетуша 2. фиг. брбљивица, торокуша; блебетало; чегртаљка. 2. фиг. особа која говори којешта, блебеће, блебетало; чегртати. 2. фиг. говорити којешта, брбљати, блебетати; чакетало 3. фиг. онај који говори којешта, који блебеће, блебетало):

(27) Он је верглао уобичајене туристичке фразе: Марко Поло је из Кине донео шпагете и барут (СрпКор2013; Политика, 9. 1. 2010).

(28) Ова клепетуша изговорила је још неколико сличних глупости... (СрпКор2013, Јарослав Хашек, Доживљаји доброг војника Швејка y Првом светском рату, књ. 1, Београд: Култура, 1989, превео Станислав Винавер).

(29) А сад на посао! ... И не трубимо о томе унаоколо! (СрпКор2013, Борислав Пекић, Беснило, Београд: БИГЗ, 1987).

\footnotetext{
${ }^{5} \mathrm{C}$ друге стране, застаревање значења примећујемо код секундарног значења им. гусле, које се у савременом српском језику веома ретко употребљава као синоним за виолину (исп. РСАНУ гусле 2. в. виолина. - Сватови иду из града под гуслама /Шен. А. 9, 168/.).
} 
Не само прозвођење звука на једноставном, примитивном инструменту (уп. $\left.\partial и п л и т u^{6}\right)$, већ и музицирање на каквом год инструменту или предмету $($ дрндати, дрндало7), па и свирање уопште (РМС: свирати 6. вулг. говорити некоме нешто што му није мило или пријатно да слуша, звоцати) посматра се као потцењена, неозбиљна или непримерена активност (РМС: трубити 2. фиг. а. разносити, иирити гласине, сензационалне вести. б. позивати; говорити /обично понављајући нешто више пута/), због чега многи глаголи с овим значењем имају пејоративна значења, а често је такав случај и код именица, посебно оних којима се именују инструменти просте грађе (уп. РСАНУ: дудук 2. фиг. погдр. глуп, ограничен човек, глупак, блесан. б. покр. тром, нерадан, лењ човек, ленштина).

\section{9. КОНЦЕПТИ КВАНТИТЕТА, ИСПУЫЕНОСТИ И ЕЛАСТИЧ-}

НОСТИ (АНКЕТА). Да бисмо испитали још неке облике концептуализације човека као инанимантног ентитета, школске 2016/17. год. спровели смо други део анкете Својства и „димензије” човека-објекта (II) ${ }^{8}$ (исп. Вељковић Станковић 2018: 204-224), којим смо - код изворних говорника српског језика (студената групе 01 Филолошког факултета у Београду) - желели испитати аспекте квантитета, испуњености и еластичности. Укупни налази презентовани су у Табели 1 (исп. ниже), а анализу резултата излажемо овде, следствено табеларном приказу.

2.9.1. ВЕЛИКИ ЧОВЕК - МАЛИ ЧОВЕК. ВеЛичина се поима као збир изразито позитивних особина које се углавном испољавају кроз саосећајан, хуман, племенит однос према другима. Значајност особе, судећи према одговорима испитаника, произилази пре свега из моралне врсности (уп. људина), а тек потом из веома вредних плодова рада и стваралаштва. Физичка одличја, тј. крупна грађа, телесна развијеност, као и истакнут друштвени положај имају периферну позицију у тумачењу значења. Уопштено истицање врлина („хиљаду добрих ствари у једној особи”) и релативно велик број атрибута употребљених зарад осликавања појма доброте показује да се у изразито позитивној представи људског бића сустичу све пожељне човекове „димензије"9 и карактеристике - ширина, дубина, мекоћа и топлина (уп. велико-

\footnotetext{
${ }^{6}$ У РСАНУ: диплити 2. фиг. пеј. покр. а. проводити време бесмислено; зазјавати; живети без онога што је потребно, нормално у животу. б. говорити којешта, брбљати.

${ }^{7}$ РСАНУ: дрндати и дрндати 2. а. рђаво, досадно, нескладно свирати (обично на инструменту са жицама). б. жаморити, жагорити; говорити којешта, наклапати, торокати; гунђати, чантрати; дрндало и дрндало в. фиг. пеј. мизучки инструмент са жицама. 2. разг. брбљива особа, наклапало.

${ }^{8}$ У анкети је учествовало 90 студената, а упитник је профилисан на исти начин као и претходна, опширнија анкета (уп. Вељковић Станковић 2018: 209-224): као одговор на први захтев требало је, уз сваку од наведених синтагми, дати бар једну холистичку карактеризацију и/или блискозначницу (придев или именицу), а други захтев се односио на слободно дефинисање синтагматских спојева. Циљ је био сагледавање организације ових концепата у целини, тј. људских особина које се на њиховом темељу могу одредити, као и типичних сценарија у којима се оне испољавају.

${ }^{9}$ У прилог чињеници да у овом домену делује метономија квантитет за квалитет сведочи и значење које РСЈ бележи за им. формат 2. фиг. вредност, способност: научник великог формата, као и израз човек од формата изванредна личност, човек великих способности, величина, aymopumem.
} 
душан, иирокогруд, племенит, доброчинитељ, алтруиста, човек и сл.). У типичном сценарију учествују појединац и група / друштво (добар човек / људина - добра дела - /руги/ људи), при чему се врлина препознаје у добробити коју деловање појединца доноси другима (уп. ДОБРОТА ЈЕ ДАВАњЕ, нпр. велик човек... брине о другима // помаже и сл.). Доминантне метафоре су: ВРЕДНОСТ ЈЕ ВЕЛИЧИНА (Лејкоф и др. $\left.{ }^{2} 1991: 14\right) \rightarrow$ ВЕЛИЧИНА ЈЕ ДУХОВНИ / ЕМОТИВНИ КАПАЦИТЕТ / ДОБРОТА (ДОБРОТА=ДАВАЮЕ), тј. ЗБИР ПОЗИТИВНИХ ОСОБИНА И ХУМАНИХ ДЕЛА(ЮА).

Судећи по односу карактеризације придевом мали и наведеним описним дефиницијама, очито је да му је у већем броју случајева придато фигуративно значење прид. низак (неморалан, нечастан, подао). Таква, негативна оцена очита је код адјектива с префиксом не-, као и код спонтано употребљених зоолексема (бубашваба, вашка, гњида, кукавица), којима се истиче морална нискост. Истовремено, те лексеме потврђују вишесмерна саодношења фигуративних значења унутар ВК и сведоче о превази пејорације у изворном домену фауне. Дакле, избор блискозначних лексема открива да је атрибут низак, у складу с метафором вертикале - ЛОШЕ ЈЕ ДОЛЕ, када је реч о етичкој и духовој миноризацији, адекватнији од прид. мали, јер потоњи, по свему судећи, не располаже довољним дерогативним потенцијалом (уп. РМС 7. а, 7. б: безначајан; немоћан, неспособан). Доминантне метафоре, као и код синтагме велики човек, произилазе из социјално оспољеног понашања: НИСКОСТ ЈЕ НЕМОРАЛНОСТ, те једним делом кореспондирају с одсуством ширине (уп. тесан човек).

2.9.2. ИСПУЬЕН ЧОВЕК - ПРАЗАН ЧОВЕК. Највећа кохерентност одговора забележена је у карактеризацији онога ко је испуњен (срећан / срећник 29 , задовољан 14, успешан 13, остварен 10); то потврђује и одсуство одговора с најнижом фреквенцијом, која по правилу расте управно пропорционално са разуђеношћу концепта. Иако прид. испуњен природно колоцира и с негативним садржајима, посебно када су у питању емоције (нпр. испуњен тугом, бесом, јадом и сл.), у спрези с им. човек подстиче афирмативна значења, из чега следи да је управо остварење животних циљева основни услов за досезање среће и задовољства. Будући да наши описни речници не бележе прид. испуњен, осим као облик трп. прид. гл. испунити, такву семантизацију, пре свега због једнодушне формулације испитаника у домену људско, треба имати на уму као актуелно фигуративно значење овог попридевљеног партиципа.

Доминантна метафора је ИСПУЊЕНОСТ ЈЕ СРЕЋА / УСПЕХ. Оба сценарија условљена су присуством, односно одсуством среће (испуњен : празан), осећаја задовољства и виталности: животни ииљеви - (не)постизање цииљева - (не)срећа / духовна (не)оствареност / (не)успех.

Насупрот виђењу испуњености, празан човек је окарактерисан као несрећан, непродуховен, незадовољан, неиспуњен и неостварен (исп. Табела 1). Како је атрибуција прид. несрећан доминантна, а велик придева у улози дескриптора грађен префиксима не- и без- (незанимљив, неосетььи, непокретан, непродуктиван; безосећајан, беживотан, бездушан, бесциљан), можемо 
закључити да се узроци одсуства среће и остварености препознају у творбеним основама наведених адјектива, и то као минус присуство. То потврђују и слободне описне дефиниције, које се по правилу јављају с негацијом (који нема вољу за животом / нема саосећајности за друге; коме ништа није важно; не налази мотивацију и сл.). Неиспуњеност се сагледава као духовна и емотивна пустош (непродуховљен, празноглавац, безосећајан, резигниран, неосетљив, пустиға и др.), друштвена самоизопштеност и инертност (усамљен/ик/), а с тим у вези и одсуство виталности (беживотан, непокретан, олупина). Водећа метафора супротна је претходној карактеризацији: ПРАЗНИНА ЈЕ НЕСРЕЋА.

2.9.3. САВИТЉИВ ЧОВЕК. Колокација с именицом човек побудила је сценарио притиска који ствара туђ утицај, па је, у складу с фигуративним значењем прид. савитљив, особа идентификована овим атрибутом оцењена као прилагодљива, флексибилна, еластична, а тек у нешто мањем броју случајева и као покорна, понизна (исп. РМС s.v. савитљив). Мада се за карактеризацију именицом конформиста определио мањи број испитаника, у дефиницијама преовлађује истицање опортунистичког понашања (уп. „своје понашање подешава и мења у зависности од ситуације"), те се као доминантне метфоре издвајају ТУЂ УТИЦАЈ ЈЕ ТЕРЕТ, ПОДЛЕГАњЕ ТУЋЕМ УТИЦАЈУ ЈЕ ПОКОРНОСТ, САВИЈАЬЕ ЈЕ ПОКОРНОСТ (УП. изр. савити ГЛаву /Кичму, рогове, врат/ пред неким = покорити се, попустити), БИТИ САВИТЉИВ ЗНАЧИ БИТИ КОНФОРМИСТ(А) / ОПОРТУНИСТИСТ(А).

2.9.4. КРХАК ЧОВЕК. Карактеризација придевом крхак недвосмислено упућује на емотивност и (следствено овој особини) на изражену слабост. Слабост се идентификује као нестабилност, немоћ, колебљивост и сл., неретко блискозначним реификатима (уп. ломљив, лабав, пориелан, свилен). Концепт се ослања на метафору ПСИХИЧКА / ФИЗИЧКА СЛАБОСТ ЈЕ СКЛОНОСТ ДЕФРАГМЕНТАЦИЈИ, преко које се непоуздана личносна структура поима као нестабилна и/или недефинисна форма ('као од стакла'; лабав, слина), а човек под теретом осећања као слабић (преосетљив, емотивац, емотивко, мекушаи) (ПРЕВЕЛИКА ЕМОТИВНОСТ ЈЕ ПСИХИЧКА СЛАБОСТ) који, у типичном сценарију, подлеже јер бива побеђен због неконзистентности властитог устројства.

\section{3. Закључни осврт}

Човек све доживљаје, утиске пропушта кроз властите филтере - чулне и мисаоне; своју спољашњу и унутрашњу ,архитектуру” позајмљује окружењу и истовремено препознаје себе у наизглед несродним облицима, структурама и својствима. Да бисмо рекли штогод о себи и свом карактеру, који се најбоље испољава у поступцима и начинима делања, улазимо у несродне домене, од њих преузимамо неке кључне особине и „заодевамо” се њима. Тако се удевамо и у концепт неживог (нпр. говоримо о паметним телефони- 
ма, (не)поуданим уређајима, симпатичним стварима, агресивним облицима итд.). Однос ових двају домена, као и осталих у оквиру ВК, успоставља се метонимијски (инанимантно за анимантно), а у поддоменима се препознаје У метафорама (општој ЧОВЕК ЈЕ ОБЈЕКАТ / МАТЕРИЈА и бројним посебним, исп. 2.3-2.9. и Вељковић Станковић 2018: 208, фн 76).

Облици људског понашања и особине које такво понашање оспољава посматрају се као облици / форме и процеси модификације тих облика и/или садржатеља, па читав низ глагола и од њих изведених придева с примарним значењем 'својство предмета X' своја фигуративна значења развија преко изворног домена форме и метафоре КАРАКТЕРНЕ ОСОБИНЕ ЧОВЕКА СУ РЕЗУЛТАТ ОБЛИКОВАҢА // ФОРМА САДРЖАТЕЉА, док се адјективне реилексеме, чија се семантика ослања на специфичности сценарија у којима се одређене особине показују (исп. Анкета, 2.9), могу сматрати холистичким метаатрибутима, јер својим фигуративним значењима обухватају читав низ људских особина и поступака који учествују у формирању карактера.

Човеков карактер посматрамо као кохерентан скуп карактеристика који, упркос индивидуалним цртама, може бити приписан већем броју људи који их деле, а особине као релативно стабилна својства која се манифестују у друштвеном окружењу. Таква, подразумевана стабилност доводи до изразите активности изворног домена форме / облика, у чијим се разноликим видовима препознају појединачне особине. У реилексеме пројектоване етноспецифичне вредности фаворизују канонски облик (за разлику од деформисаног, в. 2.6, УП. ЉУДСКА ОСОБИНА ЈЕ НАЧИН ОФОРМљЕНОСТИ), каНонску кохерентност (УП. КАРАКТЕРНА ОСОБИНА ЈЕ СПЕЦИФИЧНОСТ ОБЈЕКTA) и канонски капацитет садржатеља (исп. концепт квалитета садржатеља, в. 2.5), у односу на које се - као пожељне особине - одмеравају и у српском језику вреднују отпорност, функционалност (на основу које се схватају различити облици људских способности), степен социјалне уклопљености, емотивни капацитет и духовна снага. 
Табела 1. Анкета Својства и „димензије” човека (II)

\begin{tabular}{|c|c|c|}
\hline $\begin{array}{l}\text { СИНТАГМА } \\
\text { (придевска } \\
\text { реилексема + } \\
\text { им. човек) }\end{array}$ & $\begin{array}{c}\text { КАРАКТЕРИЗАЦИЈА } \\
\text { ЈЕДНОМ РЕЧЈУ ИЛИ } \\
\text { СИНТАГМОМ }\end{array}$ & $\begin{array}{c}\text { ДЕФИНИЦИЈА } \\
\text { (описна, нпр. онај који ...) }\end{array}$ \\
\hline $\begin{array}{l}\text { ВЕЛИКИ } \\
\text { ЧОВЕК }\end{array}$ & $\begin{array}{l}\text { људина } 16 \text {, добар (човек) } 11, \text { ве- } \\
\text { ликодушан } 7 \text {, успешан } 5 \text {, јунак } \\
3 \text {, широкогруд } 3 \text {, висок } 2 \text {, доб- } \\
\text { родушан } 2 \text {, доброчинитељ } 2 \text {, } \\
\text { племенит } 2 \text {, херој } 2 / / \\
\text { алтруиста, бизнисмен, важан, } \\
\text { висок, господин, громада, ди- } \\
\text { ван, добротвор, дружељубив, } \\
\text { значајан, лав, легенда, мек, мо- } \\
\text { ралан, несебичан, образован, } \\
\text { председник, разуман, топао, } \\
\text { узор, храбар, човек, џин, широк } \\
1 . \\
\sum-79\end{array}$ & $\begin{array}{l}\text { Велики човек је онај који ... } \\
\text { има велико срце, воли људе / } \\
\text { крупан, високог раста / чини } \\
\text { дела вредна поштовања / па- } \\
\text { метан, поштован / поседује } \\
\text { све квалитете / хиљаду доб- } \\
\text { рих ствари у једној особи } \\
\text { / морално чист, праведан / } \\
\text { срчан; позната, важна, зна- } \\
\text { чајна особа / приступачан, } \\
\text { стпљив, пун разумевања // } \\
\text { срдачан, жели да помогне / }\end{array}$ \\
\hline $\begin{array}{l}\text { МАЛИ } \\
\text { ЧОВЕК }\end{array}$ & $\begin{array}{l}\text { низак } 18 \text {, лош / зао човек } 10 \text {, } \\
\text { кецец 3, завидан } 3 \text {, човечуљак } \\
3 \text {, јадан 2, малограђанин 2, не- } \\
\text { моралан 2, патуљак } 2 \text {, саможив } \\
\text { (ац) 2, себичан 2, шкрт(ица) 2// } \\
\text { баксуз, безначајан, безвредан, } \\
\text { безобразан, бубашваба, вашка, } \\
\text { гњида, завидан, користољубив, } \\
\text { кукавица, лицемер, мизерија, } \\
\text { небитан, неважан, непросвећен, } \\
\text { несавестан, нечовек, плашљив- } \\
\text { ко, подлац, преварант, призе- } \\
\text { ман, примитиван, сиромах, си- } \\
\text { тан, сујетан, уплашен, ускогруд } \\
1 . \\
\sum-78\end{array}$ & $\begin{array}{l}\text { Мали човек је онај који је... } \\
\text { физички и морално мали / } \\
\text { задаје ниске ударце у животу } \\
\text { гледа само своје потребе и } \\
\text { бави се небитним стварима } \\
\text { / човек без вредности / ситне } \\
\text { душе / без племенитих осо- } \\
\text { бина / не помаже, али корис- } \\
\text { ти остале / спреман да науди } \\
\text { другима / неморалан, „гази } \\
\text { преко мртвих” / }\end{array}$ \\
\hline $\begin{array}{l}\text { ИСПУЬЕН } \\
\text { ЧОВЕК }\end{array}$ & $\begin{array}{l}\text { срећан / срећник 29, задовољан } \\
14, \text { успешан } 13 \text {, остварен } 10, \text { уг- } \\
\text { ледан } 8 \text {, свестран } 7 \text {, духован } 6 \text {, } \\
\text { породичан } 3 . \\
\sum-90\end{array}$ & $\begin{array}{l}\text { Испуњен човек је онај који је } \\
\text {... задовољан собом и својим } \\
\text { животом / остварио све } \\
\text { своје циљеве / живи пуним } \\
\text { плућима / испуњен духом, } \\
\text { енергијом, срећом / духовно, } \\
\text { материјално, пословно ос- } \\
\text { тварен / }\end{array}$ \\
\hline
\end{tabular}




\begin{tabular}{|c|c|c|}
\hline $\begin{array}{l}\text { ПРАЗАН } \\
\text { ЧОВЕК }\end{array}$ & $\begin{array}{l}\text { несрећан } 17 \text {, непродуховљен } 8 \text {, } \\
\text { незадовољан } 8 \text {, неиспуњен } 6 \text {, } \\
\text { неостварен } 6 \text {, празноглавац } 6 \text {, } \\
\text { шупаљ } 6 \text {, безосећајан } 5 \text {, незаин- } \\
\text { тересован } 4 \text {, беживотан } 4 \text {, нена- } \\
\text { читан } 2 \text {, усамљен(ик) } 2 / / \\
\text { беживотан, бездушан, бес- } \\
\text { циљан, досадан, испразан, } \\
\text { љуштура, незанимљив, не- } \\
\text { осетљив, непокретан, непродук- } \\
\text { тиван, олупина, равнодушан, } \\
\text { резигниран, пустиња, тужан } 1 . \\
\sum-89\end{array}$ & $\begin{array}{l}\text { Празан човек је онај који... } \\
\text { се није пронашао ни у чему, } \\
\text { чији је живот неиспуњен / } \\
\text { нема вољу за животом / нема } \\
\text { саосећајности за друге; коме } \\
\text { ништа није важно / води ис- } \\
\text { празан живот; не налази мо- } \\
\text { тивацију ни у чему око себе / } \\
\text { без осећања и духовности / }\end{array}$ \\
\hline $\begin{array}{l}\text { САВИТЉИВ } \\
\text { ЧОВЕК }\end{array}$ & $\begin{array}{l}\text { прилагодљив } 17 \text {, конформиста } \\
9 \text {, флексибилан } 6 \text {, изманипули- } \\
\text { сан } 5 \text {, послушан } 5 \text {, покоран } 5 \text {, } \\
\text { понизан } 5 \text {, еластичан } 4 \text {, неса- } \\
\text { мосталан } 4 \text {, поводљив } 3 \text {, снала- } \\
\text { жљив } 3 \text {, довитљив(ац) } 2 \text {, меку- } \\
\text { шац } 2 \text {, слаб } 2 / / \\
\text { наивчина, разгибан, лакомис- } \\
\text { лен, гибак, спретан, дружељу- } \\
\text { бив, приступачан, ломљив, раз- } \\
\text { вијен, способан, гимнастичар, } \\
\text { домишљат, бескичмењак } 1 . \\
\sum-85\end{array}$ & $\begin{array}{l}\text { Савитљив човек је онај } \\
\text { који... лако подлеже притис- } \\
\text { ку или туђем утицају / своје } \\
\text { понашање подешава и мења } \\
\text { у зависности од ситуације / } \\
\text { спреман на сваку врсту ком- } \\
\text { промиса / савија своју кичму } \\
\text { не би ли удовољио другима / } \\
\text { човек без свога ја / изузетних } \\
\text { физичких способности / }\end{array}$ \\
\hline $\begin{array}{l}\text { КРХАК } \\
\text { ЧОВЕК }\end{array}$ & $\begin{array}{l}\text { слаб / слабић 17, нежан 14, } \\
\text { (пре)осетљив 11, емотиван / } \\
\text { осећајан 10, емотивац / емотив- } \\
\text { ко } 8 \text {, ломљив 5, нестабилан } 3 \text { // } \\
\text { немоћан, издајица, лабилан, } \\
\text { слина, осетљивац, рањив, пла- } \\
\text { чљивац, плачљивко, усамље- } \\
\text { ник, незаштићен, колебљив, } \\
\text { свилен, порцелан, ситан, меку- } \\
\text { шац, лабав } 1 . \\
\sum-84\end{array}$ & $\begin{array}{l}\text { Крхак човек је онај који је... } \\
\text { емотивно нестабилан / сла- } \\
\text { башне психичке и физичке } \\
\text { конституције, кога све погађа, } \\
\text { повређује / крхког здравља / } \\
\text { нема психичку стабилност, } \\
\text { слаб, емотиван, као од стакла } \\
\text { / тешко подноси непријатне } \\
\text { ситуације, емоције, људе, не- } \\
\text { гативна мишљења других / }\end{array}$ \\
\hline
\end{tabular}




\section{ИЗВОРИ}

Лалевић 2004: Miodrag S. Lalević, Sinonimi i srodne reči srpskohrvatskog jezi$k a$, [fototipsko izd. 1974. god.], Beograd: Nolit.

PМC 1967-1976: Речник српскохрватскога књижевног језика, I-VI, Нови Сад: Матица српска.

РСАНУ 1959-2017: Речник српскохрватског књижевног и народног језика (т. I-XX), Београд: САНУ, Институт за српски језик.

PCJ 2011: Речник српскога језика (ур. Мирослав Николић), Нови Сад: Матица српска.

СрпКор 2013: Корпус савременог српског језика (СрпКор), верзија СрпКор2013, Група за језичке технологије Универзитета у Београду, 2013.

\section{ЛИТЕРАТУРА}

Аквински 2010: Toma Akvinski, Biće i suština (prir. M. Tasić), Beograd: Dereta.

Вељковић Станковић 2018: Драгана Вељковић Станковић, Како мислимо речи - прилози проучавању когнитивних аспеката српске лексике, Београд: Филолошки факултет Универзита у Београду - Јасен.

Драгићевић 2010: Рајна Драгићевић, Вербалне асочијације кроз српски језик и културу, Београд: Друштво за српски језик и књижевност Србије.

Епли и др. 2007: Nicholas Epley, Adam Waytz, John T. Cacioppo, “On Seeing Human: A Three-Factor Theory of Anthropomorphism”, Psychological Review Vol. 114 (2007), No. 4, 864-886.

Лејкоф и др. ${ }^{2}$ 1991: George Lakoff, Jane Espenson, Alan Schwartz, Master Metaphor List, Berkeley: University of California.

Перез Рул 2001/2: Carmelo Perez Rull, "The Emotional Control Metaphors", Journal of English Studies Vol. 3 (2001-2), 179-192.

Расулић 2004: Katarina Rasulić, Jezik i prostorno iskustvo, Beograd: Filološki fakultet.

Узелац 2003: Milan Uzelac, Istorija filozofije I, Vršac: Viša škola za obrazovanje vaspitača.

Dragana D. Veljković Stanković

ON ANTHROPOCENTRIC SEMANTIC DERIVATION OF REILEXEMES

IN SERBIAN

Summary

In this paper we start from the hypothesis that a semantic derivation of lexemes denoting unanimated entities is a language universality and that its outcomes based upon personification and anthropomorphization are specific in every language. The aim is to examine figurative meanings of rei- 
lexemes and cognitive-linguistic viewing of a human profile socially, emotionally and characterfully conditioned, pictured by this lexical-semantical circle in Serbian.

Key words: Serbian language, reilexemes, human properties, anthropocentric semantic derivation, figurative meaning 